\title{
Reação de resistência ao míldio e seleção de genótipos nacionais resistentes em população $F_{2}$ de alface americana
}

Júlio César de Araújo ${ }^{1}$

Luiz Antonio Augusto Gomes ${ }^{2}$

Cibelle Vilela Andrade Fiorini ${ }^{3}$

Thiago de Oliveira Dutra ${ }^{4}$

\section{Resumo}

A alface (Lactuca sativa L.) é a hortaliça folhosa mais difundida mundialmente e a mais cultivada no Brasil. Neste trabalho, objetivou-se confirmar o modo de herança da reação resistência ao míldio (B. lactucae), isolado MGLA-01, a partir de cruzamentos entre materiais contrastantes para este caráter e seleção de genótipos resistentes e mais adaptados às condições edafoclimáticas do sul de Minas Gerais. Cruzaram-se dois genitores contrastantes, a linhagem AFL-008, resistente à $B$. lactucae, e a cultivar suscetível Salinas 88 , ambas do tipo americana. 0 ensaio foi conduzido em câmara de germinação tipo BOD e em casa de vegetação. Quinze dias após a semeadura foi feita a inoculação nos genitores masculino e feminino na geração $F_{1}$, na população $F_{2}$ e em testemunha resistente, utilizando-se como inóculo os esporângios lavados de tecidos infectados na concentração de $1 \times 10^{5}$ esporângios. $\mathrm{mL}^{-1}$. A avaliação para resistência ao míldio foi realizada 15 dias após a inoculação. $O$ delineamento experimental utilizado foi inteiramente ao acaso, com três repetições.

A variável resposta foi o número de plantas sadias. Para o estudo de herança, foi feito o teste de significância qui-quadrado na população $\mathrm{F}_{2}$. No controle genético da resistência a Bremia lactucae Regel, agente etiológico do míldio da alface, o gene apresenta interação alélica de dominância, com dominância do alelo que confere resistência ao míldio.

Palavras-chaves: Lactuca sativa. Bremia lactucae. Resistência genética. Melhoramento de plantas.

\section{Introdução}

A alface (Lactuca sativa L.) é a hortaliça folhosa mais difundida mundialmente e a mais cultivada no Brasil. Entre os tipos de alface cultivados atualmente, destaca-se a alface americana, principalmente devido às características marcantes apresentadas por esse grupo (YURI et al., 2004a).

A alface tipo americana destaca-se dos demais tipos de alface por apresentar folhas externas de coloração verde-escura, folhas internas de coloração amarela ou branca, imbricadas e crocantes, semelhantes à do repolho (YURI, 2002). Esse tipo de alface apresenta também maior vida pós-coIheita, possibilitando o transporte a longas distâncias sem grandes perdas de qualidade (DECOTEAU et al., 1995).

O sul de Minas Gerais está se destacando consideravelmente na produção de alface americana destinada às redes de lanchonetes "fast foods", tornando-se polo produtor desse tipo de hortaliça (MOTA et al., 2003; YURI et al., 2004b). Por se tratar de uma olerícola de inverno, o maior desafio tem sido selecionar cultivares produtivas e com maior adaptação às condições de cultivo no Brasil e, particularmente, do sul de Minas Gerais (YURI et al., 2004b). Nessas condições problemas como

${ }^{1}$ Doutorando em Fitotecnia do Departamento de Agricultura da Universidade Federal de Lavras, Lavras, Minas Gerais, Campus Universitário UFLA, Caixa postal 3037, CEP: 37200-000, julioagro@gmail.com .

2Professor Adjunto do Departamento de Agricultura da Universidade Federal de Lavras, Lavras, Minas Gerais, Campus Universitário UFLA, Caixa postal 3037, CEP.: 37200-000; laagomes@dag.ufla.br

${ }^{3}$ Professora Adjunta da Universidade Federal Rural do Rio de Janeiro - Depto. de Agricultura, BR 465, Km 7, 23851-970 Seropédica (RJ); cibellefiorini@yahoo.com.br

${ }^{4}$ Estudante de Agronomia do Depto. de Agricultura da Universidade Federal de Lavras, Lavras, Minas Gerais, Campus Universitário UFLA, Caixa postal 3037, CEP.: 37200-000, thi.dutra@gmail.com 
pendoamento precoce, incidência de nematoides das galhas, vírus LMV (Lettuce mosaic virus) e míldio têm acarretado perdas significativas nos campos de produção de alface (SILVA, 2008).

Devido à exigência por temperaturas amenas para produção de alface americana, as regiões de clima frio são as mais indicadas. Esta exigência por temperaturas mais baixas, propicia a infestação dos campos de alface americana pelo patógeno Bremia lactucae, agente etiológico do míldio da alface. No Brasil, essa doença é importante nas regiões onde, durante o inverno, existam alta umidade e temperaturas amenas, como a região sudeste, causando grandes prejuízos aos produtores (PAVAN, KUROZAWA, 1997).

Ocasionados pelo míldio nas folhas da alface, os sintomas cloróticos e necróticos causam redução da área fotossintética e da qualidade das plantas, o que pode causar danos significativos na colheita e na pós-colheita pelo fato de possuir alto poder destrutivo e atingir diretamente a parte comercializada (BRUGGEN, SCHERM, 1997). Segundo Figueiredo (2001), a modificação ambiental devido à utilização do cultivo protegido tem contribuído para a maior ocorrência do míldio da alface. Nesse contexto, mudas produzidas em estufa podem ser atacadas desde cedo pelo patógeno.

O controle do míldio da alface é feito, principalmente, por meio do uso de cultivares resistentes, portadoras do gene Dm, normalmente expressando reação de hipersensibilidade (DALPIAN et al., 2004; BRAZ et al., 2007). Há uma necessidade de busca por novas fontes de resistência a esse patógeno, para utilização imediata no melhoramento genético da alface, contribuindo não só com a diminuição do custo de produção da cultura, mas também com os impactos ambientais e de risco à saúde humana, causados pela aplicação indiscriminada de defensivos agrícolas.

A cultivar Salinas 88 já é citada como resistente ao nematoide-das-galhas, apresenta também resistência ao LMV - patótipos I, II e III - sendo portadora do gene recessivo mo $^{2}$ (STANGARLIN et al., 2000). Essa cultivar é do tipo americana, mas apresenta problemas de formação de cabeça nas condições climáticas brasileiras, no entanto, é um material de grande importância para ser utilizado em programas de melhoramento da alface (SILVA, 2008).

Diante do exposto, neste trabalho, objetivou-se confirmar o modo de herança da resistência ao míldio, isolado MGLA-01, a partir de cruzamento entre materiais contrastantes para este caráter, no intuito de selecionar genótipos de alface americana resistentes a este patógeno e mais adaptados às condições edafoclimáticas do sul de Minas Gerais.

\section{Material e métodos}

A partir do cruzamento entre Salinas 88 (tipo americana, resistente ao nematoide-das-galhas e ao vírus do mosaico-da-alface - LMV, patótipos I, II e III, e sensível ao florescimento precoce) e da Linhagem ALF-008 (material experimental nacional do tipo americana, suscetível ao nematoide-das -galhas e ao LMV, resistente ao míldio e tolerante ao florescimento precoce), populações $F_{1}$ de alface foram obtidas por meio de hibridações realizadas em casa de vegetação, nas dependências da Horti Agro Sementes Ltda., no Município de ljaci (MG), entre março e julho de 2008 (altitude 920 m, 21 ${ }^{\circ}$ $14^{\prime} \mathrm{S}$ e $45^{\circ} \mathrm{W}$ ). As sementes híbridas $\mathrm{F}_{1}$ foram avançadas para $\mathrm{F}_{2}$ no período de setembro a dezembro de 2008, a população $F_{2}$ foi denominada AFBX-001.

Os esporângios de $B$. lactucae utilizados neste trabalho foram coletados nos meses de junho a agosto dos anos de 2008 e $2009^{5}$, em plantas de alface, em estufas de produção de mudas de alface e na área experimental do Setor de Olericultura do Departamento de Agricultura da Universidade de Lavras (UFLA), em Lavras (MG). As folhas que apresentavam sintomas da doença com esporulação visível foram colocadas em sacos plásticos, devidamente identificados e levados ao laboratório. 0 míldio, por ser considerado um fitoparasita de caráter biotrófico obrigatório (multiplica-se somente em

${ }^{5} \mathrm{O}$ processo de hibridação foi realizado um ano antes de testes de resistência e controle genético, pois é um processo que é trabalhoso e requer tempo, porque implica em plantio escalonado dos materiais para um sincronismo da antese dos progenitores, para posterior emasculação, cruzamento forçado, identificação das flores, amadurecimento, colheita, beneficiamento das sementes e armazenamento por pelo menos trinta dias em câmara fria e escura para evitar desuniformidade de germinação causada por termodormência das sementes, a partir daí seguindo para um novo plantio para obtenção da população $F_{2}$ (altamente segregantes) por autofecundarão do $F_{1}$ ( $100 \%$ de heterose) passando por todo o ciclo descrito anteriormente, para só após começarem a ser realizados os testes de resistência e controle genético, além do que precisa-se pelo menos de três gerações para avaliar o tipo de herança genética. Porém em paralelo a esse processo já estava sendo coletado o material fitopatogênico (míldio) para estudo e definição dos protocolos de multiplicação, inoculação, armazenamento, materiais resistentes e testes preliminares como forma de garantir uma maior precisão dos ensaios, porque o material híbrido $F_{1}$ é de difícil obtenção (alface é cleistogâmica, sendo altamente autógama), não havendo muito espaço para erros na condução dos demais passos do trabalho, que poderia resultar em perda de tempo de pelo menos um ano de trabalho. 
hospedeiro vivo), foi replicado periodicamente em plântulas de alface em câmara de germinação tipo BOD com controle de temperatura, fotoperíodo e umidade, para manutenção do volume inóculo para os testes experimentais. Foi criado um banco de esporos, para garantir o armazenamento de amostras do isolado coletado na região de Lavras (MG), denominado para fins de pesquisa de MGLA-01. As amostras do isolado foram seladas em caixas de cultura e armazenadas em freezer, a temperatura de $-20{ }^{\circ} \mathrm{C}$, metodologia descrita por Michelmore e Crute (1983).

O experimento de reação de resistência ao míldio foi conduzido em condições de laboratório no setor de Fitopatologia da Universidade Federal de Lavras (UFLA), no período de junho a agosto de 2009. A UFLA situa-se no Município de Lavras, sul de Minas Gerais, a uma altitude média de 910 m, a $21^{\circ} 14^{\prime} \mathrm{S}$ e $45^{\circ} 0^{\prime} \mathrm{W}$. O clima da região, segundo a classificação de Köppen, é do tipo Cwb, caracterizado por uma estação seca entre abril e setembro e uma estação chuvosa de outubro a março.

Para a avaliação da reação de resistência ao míldio foram utilizados cinco genótipos de alface, sendo eles as cultivares Salinas 88, linhagem ALF-008, o híbrido $F_{1}$, geração $F_{2}$ e a cultivar Colorado (testemunha resistente, portadora do gene Dm 18). Foi utilizado o delineamento experimental inteiramente ao acaso, com três repetições. Cada parcela foi composta por uma caixa gerbox com quarenta plântulas. Os tratamentos foram semeados em caixas de acrílico transparente tipo gerbox ( 11 X 11 $X 2 \mathrm{~cm}$ ), sobre papel de germinação (mata-borrão) umedecido com água destilada. Todas as etapas descritas acima foram realizadas sob câmara de fluxo laminar, para evitar contaminação por agentes externos, e estas caixas gerbox contendo as sementes foram colocadas em câmaras de germinação (incubadora tipo BOD) à temperatura constante de $20^{\circ} \mathrm{C}$ e fotoperíodo de 10 horas. Quinze dias após a semeadura, foi feita a inoculação das plântulas de alface, estas com os cotilédones completamente expandidos, utilizando esporângios do míldio ( $B$. lactucae) de acordo com a técnica descrita por llott et al. (1987), utilizando-se esporângios lavados de tecidos infestados do hospedeiro e agitados em água destilada. Os esporângios foram suspensos em água destilada, na concentração de 1 x 105 esporângios. $\mathrm{mL}^{-1}$ e pulverizados nas plântulas até o ponto de escorrimento. Para a contagem do número de esporângios, realizada em microscópio óptico, foi colocado em um hemacitômetro (câmara de Neubauer) $1 \mu \mathrm{L}$ da suspensão de esporângios previamente homogeneizada. Após a inoculação, as plântulas foram recolocadas em câmaras de germinação, à temperatura de $13^{\circ} \mathrm{C}$ e umidade relativa (UR) acima de $80 \%$. Nas seis primeiras horas, as plântulas foram deixadas em câmara escura para germinação dos esporangióforo e liberação do esporângios, após esse tempo, o fotoperíodo foi reajustado para 12 horas. As avaliações para resistência ao míldio foram feitas quinze dias após a inoculação, sendo cada plântula avaliada individualmente, verificando-se a presença ou não de sintomas e esporulação.

Os dados foram submetidos à analise de variância para detecção da presença de variabilidade genética e, em seguida, os valores foram ordenados segundo o agrupamento de Scott-Knott a 5\% de probabilidade. As análises estatísticas foram realizadas com o auxílio do programa SISVAR (FERREIRA, 2000).

O experimento para testar o modo de herança genética para resistência ao míldio e selecionar os genótipos nacionais resistentes foi conduzido em condições de laboratório no setor de Fitopatologia e em casa de vegetação do setor de Olericultura da UFLA, de julho a setembro de 2009. Foram semeadas 1.200 sementes $F_{2}$ (AFBX-001), 120 sementes do parental materno suscetível (Salinas 88), 120 sementes do parental masculino resistente (ALF-008), 80 sementes do híbrido $\mathrm{F}_{1}$ (ALF-008 x Salinas 88) e 80 sementes da cultivar Colorado (testemunha resistente, portadora do gene Dm 18), em caixas de acrílico transparente tipo gerbox, sobre papel de germinação umedecido com água destilada. Todas as etapas descritas acima foram realizadas sob câmara de fluxo laminar, para evitar contaminação por agentes externos, e estas caixas gerbox contendo as sementes foram colocadas em câmaras de germinação à temperatura constante de $20{ }^{\circ} \mathrm{C}$ e fotoperíodo de 10 horas. Quinze dias após a semeadura, foi feita a inoculação das plântulas de alface, estas com os cotilédones completamente expandidos, utilizando esporângios do míldio, utilizando-se esporângios lavados de tecidos infestados do hospedeiro e agitados em água destilada. Os esporângios foram suspensos em água destilada, na concentração de $1 \times 10^{5}$ esporângios. $\mathrm{mL}^{-1}$ e pulverizados nas plântulas até o ponto de escorrimento. Para a contagem do número de esporângios realizada em microscópio óptico, foi colocado em um hemacitômetro $1 \mu \mathrm{L}$ da suspensão de esporângios previamente homogeneizada. Após a inoculação, as plântulas foram recolocadas em câmaras de germinação, à temperatura de $13^{\circ} \mathrm{C}$ e umidade relativa acima de $80 \%$. Nas seis primeiras horas, as plântulas foram deixadas em 
câmara escura para germinação do esporangióforo e liberação dos esporângios, após este tempo, o fotoperíodo foi reajustado para 12 horas. A seleção dos genótipos nacionais de alface americana para resistência ao míldio foi feita quinze dias após a inoculação, sendo cada plântula avaliada individualmente, verificando-se a presença ou não de sintomas e esporulação.

Para o estudo de herança, foi realizado o teste de significância Qui-quadrado ( $\chi 2)$ na população $\mathrm{F}_{2}$, em que se testou a hipótese $\mathrm{HO}$ formulada, segundo a qual a "segregação gênica desse caráter é de 3:1, ou seja, a ação gênica é dominante". A expressão para o teste de significância qui-quadrado ( $\chi 2)$ (RAMALHO et al., 2000) foi o seguinte:

$$
\chi 2=\Sigma[(\mathrm{FO}-\mathrm{FE}) / \mathrm{FE}]
$$

onde:

FO: frequência observada na população segregante;

FE: frequência esperada na população segregante.

\section{Resultados e discussão}

A análise de variância evidenciou diferenças significativas $(P \leq 0,05)$ quanto à re-ação de resistência ao míldio ( $B$. lactucae) entre as gerações estudadas (Tabela 1 ).

Tabela 1. Médias de plântulas sadias (\%), dos genitores maternos $\left(P_{1}\right)$ e paterno $\left(P_{2}\right)$, da geração $F 1$, geração $F_{2}$ e da testemunha, em genótipos de alface avaliados para resistência ao isolado MGLA-01 do fungo Bremia lactucae Regel. (LAVRAS, UFLA, 2009)

\begin{tabular}{lcc}
\hline Famílias & Genótipos & \% plântulas sadias \\
\hline $\mathrm{P}_{1}$ & Salinas 88 & $0 \mathrm{c}$ \\
$\mathrm{P}_{2}$ & ALF-008 & $100,0 \mathrm{a}$ \\
$\mathrm{F}_{1}$ & ALF-008x Salinas 88 & $100,0 \mathrm{a}$ \\
$\mathrm{F}_{2}$ & AFBX-001 & $74,1 \mathrm{~b}$ \\
Testemunha & Colorado (Gene Dm 18) & $100,0 \mathrm{a}$ \\
\hline $\mathrm{CV}(\%)$ & & 0,91 \\
Média geral & & 74,82 \\
\hline
\end{tabular}

* Médias seguidas da mesma letra não diferem estatisticamente entre si, pelo teste Scott-Knott, a 5\% de probabilidade.

Fonte: Elaboração dos autores.

Observa-se, pelos dados da Tabela 1, que o coeficiente de variação experimental (CV) na análise de variância foi baixo, apresentando assim, um erro estimado pequeno, comprovando a eficiência da metodologia utilizada neste estudo. A eficiência da procura por linhagens resistentes a patógenos em um programa de melhoramento de plantas depende da precisão com que as avaliações são realizadas, essa precisão experimental pode ser avaliada por alguns procedimentos específicos e um dos mais utilizados é a estimativa do coeficiente de variação experimental (RAMALHO et al., 2000).

A porcentagem das médias de plântulas sadias da cultivar Colorado (testemunha resistente, de gene Dm18), da linhagem ALF-008 (genitor masculino resistente) e da geração $F_{1}$ (ALF-008 $x$ Salinas 88) foi superior à dos demais genótipos, conforme o teste de médias de Scott-Knott - 5\% (Tabela 1), atingindo um total de 100\% de plântulas desprovidas de sintomas e esporulação (plântulas sadias) demonstrando a resistência destes materiais ao míldio (Figura 1). Para a cultivar Salinas 88 (genitor feminino suscetível) observou-se que não houve plântulas sadias, evidenciando a alta suscetibilidade desse genótipo ao míldio (Figura 2). É importante salientar que geração $\mathrm{F}_{2}$ manteve uma porcentagem média de $74,1 \%$ de plântulas sadias, evidenciando a ocorrência de segregação e confirmando o sucesso dos cruzamentos entre o genitor resistente e suscetível. 0 desvio amostral de 
menos de $1 \%$, foi devido ao acaso, sendo assim não significativo, ou seja, o resíduo é, na realidade, a causa do desvio observado.

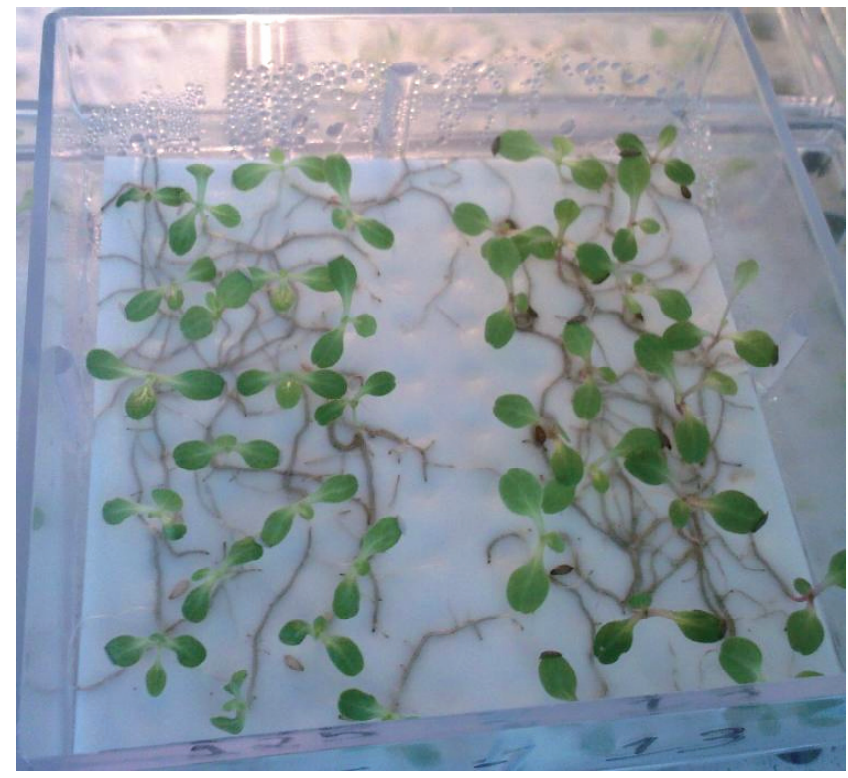

Figura 1. Ausência de sintomas e esporulação nas plântulas dos genótipos resistentes inoculadas com míldio. (LAVRAS, UFLA, 2009).

Fonte: Elaboração dos autores.

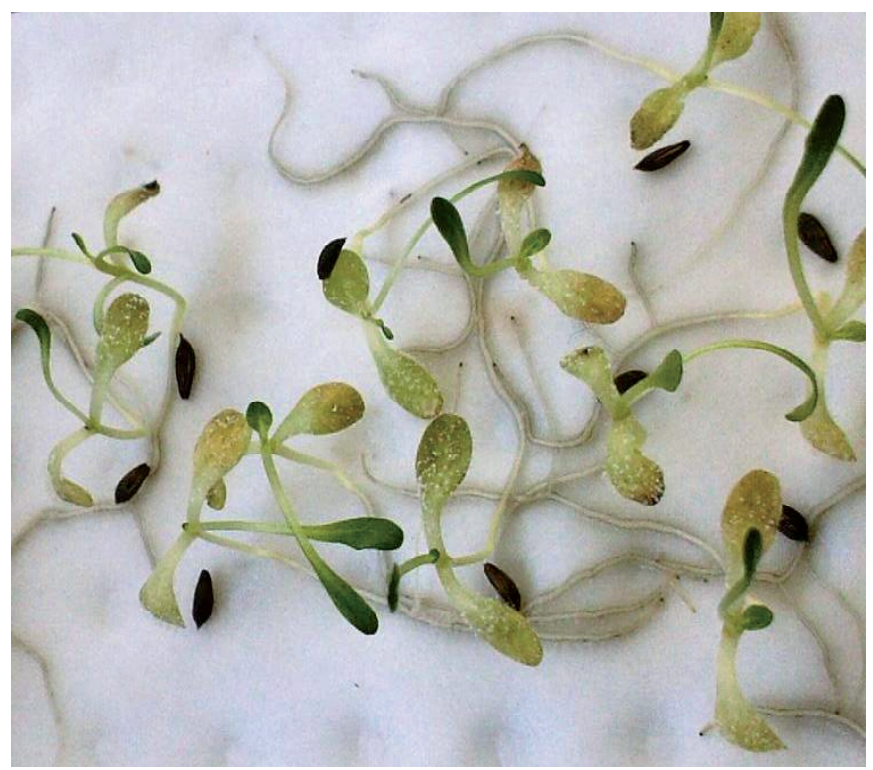

Figura 2. Clorose, necrose e esporulação em plântulas dos genótipos suscetíveis inoculadas com míldio. (LAVRAS, UFLA, 2009).

Fonte: Elaboração dos autores.

Constata-se, pelos dados da Tabela 2, que os genitores utilizados, Salinas 88 e ALF-008, confirmaram sua reação de resistência ou suscetibilidade, respectivamente, obtida em avaliações prévias. A linhagem testemunha Colorado, portadora do gene Dm 18, também confirmou sua reação de resistência em todos os experimentos avaliados, semelhantes a resultados obtidos por Braz et al. (2007) no estudo de raças de B. lactucae realizados no estado de São Paulo. A obtenção de 100\% de plantas resistentes na geração $F_{1}$ (ALF-008 x Salinas 88) e de 74,3\% de plantas resistentes na geração F2 (AFBX-001) indica a possibilidade de o controle genético ser devido a um único gene com 
efeito de dominância completa, conforme a proporção de plantas resistentes e suscetíveis esperadas para esta geração (proporção de 3:1).

Tabela 2 Segregação para reação ao patógeno Bremia lactucae Regel, na geração $F_{2}$ e a reação de resistência nos genitores, geração $F_{1}$ e na testemunha resistente. (LAVRAS, UFLA, 2009).

\begin{tabular}{lccccc}
\hline Famílias & $\begin{array}{c}\text { \% plântulas } \\
\text { resistentes }\end{array}$ & $\begin{array}{c}\text { Plântulas } \\
\text { suscetíveis } \\
(+)\end{array}$ & $\begin{array}{c}\text { Plântulas } \\
\text { resistentes } \\
(-)\end{array}$ & $\begin{array}{c}X 2 \\
3: 1\end{array}$ & $P$ \\
\hline $\mathrm{P}_{1}$ (Salinas 88) & 0,0 & 104 & 0 & & \\
$\mathrm{P}_{2}$ (ALF-008) & 100,0 & 0 & 117 & & \\
$\mathrm{~F}_{1}($ ALF-008 x Salinas 88) & 100,0 & 0 & 79 & & $0,6-$ \\
$\mathrm{F}_{2}$ (AFBX-001) & 74,3 & 278 & 804 & 0,277 * & 0,7 \\
Colorado (Testemunha) & 100,00 & 0 & 77 & & \\
\hline
\end{tabular}

* Teste qui-quadrado, a $5 \%$ de probabilidade.

Fonte: Elaboração dos autores.

Ao se fazer o teste de chi-quadrado $(\chi 2)$ verifica-se que, os valores esperados se ajustam aos valores obtidos, considerando a hipótese de herança monogênica e controle genético de dominância completa (Tabela 2). 0 modelo utilizado nas estimativas dos componentes de variância foi suficiente para explicar toda a variação observada. As estimativas do teste de significância com $1 \mathrm{Gl}$ ( $\chi 2 \mathrm{calc}=$ 0,277 ) situaram-se entre os níveis de $60 \%$ e $70 \%$ de probabilidade de que os desvios ocorridos sejam devidos ao acaso, não sendo significativos (Tabela 3). Esses resultados indicam que a herança da resistência é controlada por um loco com dois alelos e presença de dominância do alelo que confere resistência sobre o alelo que confere suscetibilidade.

Tabela 3 Frequência observada, esperada e desvio de cada fenótipo na geração $F_{2}$, relativos ao estudo de herança da resistência ao patógeno Bremia lactucae em plântulas de alface. (LAVRAS, UFLA, 2009).

\begin{tabular}{lccccc}
\hline Fenótipo $\mathrm{F}_{2}$ & $\mathrm{FO}$ & $\mathrm{FE}$ & Desvio & Desvio $^{2}$ & $\chi^{2}=$ Desvio $^{2} / \mathrm{FE}$ \\
\hline Resistente & 804 & 811,5 & $-7,5$ & 56,25 & 0,069 \\
Suscetível & 278 & 270,5 & 7,5 & 56,25 & 0,208 \\
\hline
\end{tabular}

* Teste qui-quadrado, a 5\% de probabilidade. $\quad \chi 2$ tab 0,05 $=3,84$

** HIPÓTESE HO: a segregação é de 3:1, ou seja, a ação gênica é dominante. Com 1 Gl, o valor de $\chi 2$ calculado de 0,277.

Fonte: Elaboração dos autores.

A segregação encontrada nesse estudo é coerente com os resultados obtidos com relação às estimativas dos componentes de variância, que evidenciaram a presença de dominância na manifestação do caráter. Esse resultado de segregação reafirma inferências feitas por Dalpian (2005), que em experimentos de melhoramento de alface para resistência ao patógeno $B$. lactucae, utilizando como genitores as cultivares de alface crespa Colorado (resistente) e Hortência (suscetível) encontrou resultados positivos na seleção de famílias homozigóticas resistentes para esse caráter.

Os resultados de controle genético encontrados no presente estudo também cor-roboram os resultados obtidos por Zink (1973), Crute e Jhonson (1976) e Johnson et al. (1978), nos quais os genes Dm estudados em outras linhagens de alface resistentes B. Lactucae também apresentam interação alélica de dominância. De acordo com Crute e Lebeda (1981), a resistência do gene Dm é controlada por um único alelo dominante, que é acompanhado por genes de avirulência no gênero Bremia, em uma relação de interação gene-a-gene, ou seja, para a especificidade de raças. As relações de interação gene-a-gene resultam numa interação incompatível entre o patógeno e a planta, associado com uma resposta de hipersensibilidade do hospedeiro, que bloqueia a infecção da doença e posteriormente a dispersão do patógeno. Braz et al. (2007) constaram que no controle genético da 
alface para resistência aos comportamentos de $B$. lactucae encontrados nos campos brasileiros de produção de alface estão envolvidos diferentes genes $\mathrm{Dm}$, com o alelo dominante sendo o responsável pela resistência, para todos os comportamentos estudados.

Segundo Dalpian et al. (2004), Braz et al. (2007) e Pissardi et al. (2005), o comportamento mais encontrado de $B$. lactucae, nas principais regiões produtoras de alface do estado São Paulo e em Santana da Vargem (cidade da região sul de Minas Gerais), é o descrito como comportamento 63/63/51/00 pelo sistema de Código Sextets, proposto por Van Ettekoven e Van Der Arend (1999), comportamento esse considerado uma raça, para a qual se propôs a denominação SPBI- 01. Castoldi et al. (2010), recomendam a utilização dos genes DM-17, DM-18 e DM-38 como fontes de resistência nas cultivares desenvolvidas, pois esses genes conferem resistência a todas as raças de míldio da alface já catalogadas no Brasil. 0 uso da linhagem ALF-008 em programas de melhoramento de alface voltados para as condições brasileiras pode ser viável, por apresentar resistência ao míldio semelhante à cultivar Colorado (gene $\mathrm{Dm}$ 18), demonstrando também ter um único gene com efeito de dominância completa. Diante desse fato, as sementes colhidas nas plantas $F_{2}$ selecionadas neste estudo, darão origem às famílias $F_{2.3}$ pela condução de população segregantes pelo método pedigree, que poderão ser utilizadas para a obtenção de linhagens nacionais de alface americana resistentes ao míldio.

\section{Conclusão}

No controle genético da resistência a Bremia lactucae Regel, agente etiológico do míldio da alface, o gene apresenta interação alélica de dominância. No controle da resistência estão presentes um ou poucos genes estreitamente ligados, com dominância completa do alelo que confere resistência.

As plantas selecionadas da geração $F_{2}$ são resistentes ao fungo Bremia lactucae, isolado, denominado MGLA-01, e podem ser avançadas no processo de seleção para a obtenção de linhagens nacionais de alface americana resistentes ao míldio.

\section{Agradecimentos}

Ao Conselho Nacional de Desenvolvimento Científico e Tecnológico; à Fundação de Amparo à Pesquisa do Estado de Minas Gerais e à Fundação de Apoio ao Ensino, Pesquisa e Extensão da Universidade Federal de Lavras, pelo financiamento da pesquisa; à Universidade Federal de Lavras e à HortiAgro Sementes Ltda., pela infraestrutura.

\section{Reaction of resistance to downy mildew and selection of re- sistant national genotypes in the $F_{2}$ population of iceberg- lettuce}

\section{Abstract}

In this study, we tried to confirm the inheritance mode of resistance to downy mildew ( $B$. lactucae) MGLA-01 isolated by crossing among contrasting materials for this character, in order to select resistant genotypes and better adapted ones to the ecological conditions of southern Minas Gerais. It was used in hybridization, two contrasting parents the lineage AFL-008 (resistant to B. lactucae) and cultivar Salinas 88 (susceptible to $B$. lactucae) both american-type materials. The trial was conducted in a germination chamber type BOD and in the greenhouse. Fifteen days after sowing, inoculation was made in the maternal and paternal parents, $F_{1}$ generation, the $F_{2}$ population and withess tough, using as inoculum the washed infected tissues sporangium at a concentration of $1 \times 105$ sporangium. $\mathrm{mL}^{-1}$. The evaluation for resistance to downy mildew was held 15 days after inoculation. 
The experimental design was completely random with three replications. For data analysis we used as a response variable the number of healthy plants. For the inheritance study, we made a significance test Chisquare in the F2 population. In genetic resistance control to Bremia lactucae Regel, the causal agent of lettuce downy mildew, the gene shows allelic interaction of dominance, with dominant allele which confers resistance mildew.

Key words: Lactuca sativa. Bremia lactucae. Genetic resistance. Plant breeding.

\section{Referências bibliográficas}

BRAZ, L. T.; DALPIAN, T.; CAMARGO, M.; PISSARDI, M. A. Identification of races of Bremia lactucae in São Paulo. Acta Horticulturae, The Hague, v. 1, n. 760, p. 317-321, 2007.

BRUGGEN, A. H. C. van; SCHERM, H. Downy mildew. In: DAVIS, R. M.; SUBBA-RAO, K. V.; KURTS, E. A. Compedium of lettuce diseases. Saint Paul: American Phytopathological Society, 1997. p. 1719.

CASTOLDI R.; CHARLO H. C. O.; DALPIAN T.; MELO D. M.; BRAZ L. T. Identificação de raças de Bremia lactucae em alface no Estado de São Paulo, durante o ano de 2009. 2010. Horticultura Brasileira 28: S971-S976.

CRUTE, I. R.; JHONSON, A. G. Breeding for resistance to lettuce downey mildew, Bremia lactucae. Annals of Applied Biology, Warwick, v. 84, n. 2, p. 287-290, Oct. 1976.

CRUTE, I. R.; LEBEDA, A. Evidence for a race-specific resistance factor in some lettuce (Lactuca sativa L.) cultivars previously considered to be universally susceptible to Bremia lactucae Regel. Theoretical and Applied Genetics, Berlin, v. 60, n. 3, p. 185-189, May 1981.

DALPIAN, T. Identificação das raças de Bremia lactucae que ocorrem nas principais regiões produtoras do estado de São Paulo, e obtenção de linhagens de alface crespa resistentes. 2005. $47 \mathrm{f}$. Tese. (Doutorado em Genética e Melhoramento de Plantas) - Faculdade de Ciências Agrárias e Veterinárias de Jaboticabal, Jaboticabal, 2005.

DALPIAN, T.; BRAZ, L. T.; MARGARETE, C. Identificação das raças de Bremia lactucae que ocorrem na região de Campinas (SP). Horticultura Brasileira, Campinas, v. 22, n. 2, abr. 2004. CD-ROM.

DECOTEAU, D. R.; RANWALA, D.; MCMAHON, M. J.; WILSON, S. B. The lettuce growing handbook: botany, field procedures, growing problems, and postharvest handling. Illinois: Oak, 1995. 60 p.

ETTEKOVEN, K.; AREND, A. van der. Identification and denominationof new races of Bremia lactucae. In: EUCARPIA MEETING ON LEAFY VEGETABLES GENETICS AND BREEDING, 1999, Olomuc. Procedings... Olomouc: IBEB, 1999. p. 105-107.

FERREIRA, D. F. Análises estatísticas por meio do SISVAR (Sistema para Análise de Variância) para Windows 4. 0. In: REUNIÃO ANUAL DA REGIÃO BRASILEIRA DA SOCIEDADE INTERNACIONAL DE BIOMETRIA, 45., 2000, São Carlos. Anais... São Carlos: UFSCar, 2000. p. 255-258.

FIGUEIREDO, M.B. Doenças fúngicas emergentes em grandes culturas. Biológico. São Paulo, v. 63, n. 1-2, p. 29-32, jan.-dez. 2001.

ILOTT, T. W.; DURGAN, M. E.; MICHELMORE, R. W. Genetics of virulence in California populations of Bremia lactucae (Lettuce Downy Mildew). Phytopathology, Saint Paul, v. 77, n. 10, p. 1381-1386, Oct. 1987. 
JOHNSON, A. G.; LAXTON, S. A.; CRUTE, I. R.; GORDON, P. L. L.; NORWOOD, J. M. Further work on the genetics of race specific resistance in lettuce (Lactuca sativa) to downy mildew (Bremia lactucae). Annals of Applied Biology, Warwick, v. 89, n. 2, p. 257-264, July 1978.

MICHELMORE R. W., CRUTE I. R. (1983): A method for determining the virulence phenotypes of isolates of Bremia lactucae. Trans Br Mycol Soc 79:542-546.

MOTA, J. H.; YURI, J. E.; FREITAS, S. A.C.; RODRIGUES JUNIOR, J. C.; RESENDE, G. M.; SOUZA, R. J. Avaliação de cultivares de alface americana durante o verão em Santana da Vargem (MG). Horticultura Brasileira, Brasília, v. 21, n. 2, p. 234-237, abr.-jun. 2003.

PAVAN MA; KUROZAWA C. Doenças da Alface. In: KIMATI, H. et al. Manual de Fitopatologia: Doenças das plantas cultivadas. v. 2, São Paulo: Ceres, 1997. p. 18-25.

PISSARDI, M. A.; DALPIAN, T.; BRAZ, L. T.; CAMARGO, M. Identificação do comportamento de Bremia lactucae no pólo produtor de alface americana do Sul de Minas Gerais. In: CONGRESSO BRASILEIRO DE OLERICULTURA, 45., 2005, Fortaleza. Anais... Brasília: Associação Brasileira de Horticultura, 2005. CD ROM.

RAMALHO, M. A. P.; FERREIRA, D. F.; OLIVEIRA, A. C. Experimentação em genética e melhoramento de plantas. Lavras: UFLA, 2000. 360 p.

SILVA, R. R.; GOMES, L. A. A.; MONTEIRO, A. B.; MALUF, W. R.; CARVALHO FILHO, J. L. S.; MASSAROTO, J. A. Linhagens de alface-crespa para o verão resistentes ao Meloidogyne javanica e ao vírus mosaico-da-alface. Pesquisa Agropecuária Brasileira. 2008, v.43, n.10, p. 1347-1356.

STANGARLIN, O. S. ; PAVAN, M. A.; SILVA, N. da . Occurrence of New Pathotype of Lettuce virus on Lettuce in Brazil. Plant Disease. St. Paul, v. 84, p. 490-490, 2000.

YURI, J. E.; MOTA, J. H.; SOUZA, R. J. de; RESENDE, G. M. de; FREITAS, S. A. C.; RODRIGUES JÚNIOR, J. C. Alface americana: cultivo comercial. Lavras: UFLA, 2002. 51 p.

YURI, J. E.; MOTA, J. H.; RESENDE, G. M. de; SOUZA, R. J. de; RODRIGUES JÚNIOR, J. C. Desempenho de cultivares de alface tipo americana em cultivo de outono no sul de Minas Gerais. Ciência e Agrotecnologia, Lavras, v. 28, n. 2, p. 282-286, mar-abr. 2004a.

YURI, J. E.; RESENDE, G. M.; MOTA, J. H.; SOUZA, R. J.; RODRIGUES JÚNIOR, J. C. Comportamento de cultivares e linhagens de alface americana em Santana da Vargem (MG), nas condições de inverno. Horticultura Brasileira, Brasília, v. 22, n. 2, p. 322-325, abr.-jun. 2004b.

ZINK, F. W. Inheritance of resistance to downy mildew (Bremia lactucae Reg.) in lettuce. Journal of the American Society for Horticultural Science, Alexandria, v. 98, p. 293-296, May, 1973.

Histórico

Recebido em: 02/05/2013

Aceito em: 30/07/2013 